Kamil Niewiński

Uniwersytet w Białymstoku e-mail: kamilnwsk18@gmail.com telefon: +48 857457153

DOI: $10.15290 /$ mhi.2015.14.02.11

\title{
Ministerstwo Sprawiedliwości wobec sędziowskich postulatów samorządowych w latach 1980-1981
}

\author{
SUMMARY \\ Ministry of Justice Against Self-governing Demands of the Judges \\ in the Years 1980-1981
}

The judiciary in the Polish People's Republic was not a separate, self-governing sphere of power. The judiciary was under the supervision of the Polish United Workers Party (PZPR) and the Ministry of Justice. Political and executive authorities decided upon the staffing and professional matters of judges. In autumn 1980, on the basis of the August Agreements, independent trade unions of judiciary workers were formed in the courts. Judges, associated in them, put forward their own demands and thanks to the strength of trade unions they exerted pressure on the Minister of Justice seeking chances to push through systemic changes, which would guarantee independence and self-governance of the judiciary. Implementation of the judges demands would deprive the PZPR and the Ministry of Justice of the ability to govern in the sphere of justice. The authorities did not intend to resign from these prerogatives. But the Ministry of Justice, devoid of PZPR political support, gradually gave way to the judges demands. As a result of ongoing discussion in the Ministry of Justice in the years 1980-1981, two concepts of self-governance of the judiciary were created: the judges concept of decision-making self-governance and the ministerial concept of quasi self-governance with consultative prerogatives. They were reflected in multi-variant draft amendment to the law on common courts, prepared by the Ministry of Justice in November 1981. The ministerial concept became the basis of subsequent changes made in the reform of the judiciary, performed under the dictation of the PZPR in 1984-1985. Concepts from the years 1980-1981 evolved and became the basis for the reform of the judiciary system in the systemic transition period in 1989. In great measure, self-governance of the judges functions to this day on the basis of the solutions developed in 1980-1981.

Key words: judges, judiciary, self-government, Ministry of Justice, "Solidarity" Trade Union

Słowa kluczowe: sędziowie, wymiar sprawiedliwości, Ministerstwo Sprawiedliwości, postulaty sędziowskie, NSZZ „Solidarność" 


\section{Sędziowskie postulaty samorządowe po sierpniu $1980 \mathrm{r}$.}

Społeczny ruch odnowy w Polsce Ludowej zapoczątkowany strajkami robotniczymi, porozumieniami z Sierpnia 1980 r. i narodzinami NSZZ „Solidarność" przeniknął także do środowiska sędziowskiego. W październiku w sądownictwie powstały dwa nowe związki zawodowe, sekcja branżowa Pracowników Wymiaru Sprawiedliwości w ramach NSZZ "Solidarność (NSZZ "S" PWS) oraz autonomiczny, branżowy Niezależny i Samorządny Związek Zawodowy Pracowników Wymiaru Sprawiedliwości (NSZZ PWS), który w obliczu rosnących wpływów radykalnego ruchu "Solidarności” w sądownictwie uzyskał poparcie Ministerstwa Sprawiedliwości. Do nurtu odnowy włączyło się blisko $70 \%$ sędziów i asesorów sądów rejonowych (SR), wojewódzkich (SW) oraz okręgowych sądów pracy i ubezpieczeń społecznych (OSPiUS). NSZZ „S" PWS uzyskał dominującą pozycję $\mathrm{w}$ sądownictwie zrzeszając ponad połowę pracowników zatrudnionych w Ministerstwie Sprawiedliwości i jednostkach mu podległych (ok. 10000 członków), w tym blisko 1000 sędziów i asesorów SR, SW i OSPiUS, tj. ok. $26 \%$ ogółu. NSZZ PWS, choć pod względem liczby członków zdecydowanie słabszy od "Solidarności” sądowej, uzyskał znacznie większe poparcie w środowisku sędziowskim, zrzeszając ponad 1600 sędziów i asesorów, ok. $43 \%$ ogółu ${ }^{1}$.

Przynależność sędziów do związków zawodowych mogła budzić wątpliwości. Postawę większości środowiska uzasadniała jednak sytuacja ustrojowa i społeczno-polityczna, w jakiej funkcjonowało sądownictwo w PRL. Nie było ono wyodrębnioną, niezależną sferą władzy, a środowisko sędziowskie nie było samorządne. O obsadzie stanowisk sędziowskich i sprawach zawodowych sędziów decydowały organy władzy politycznej i wykonawczej oraz kierownictwo administracyjne sądów. Ich ocenie podlegała także merytoryczna praca sędziów. Minister sprawiedliwości dysponował prawem wysuwania kandydatów na stanowiska sędziowskie, mógł wnioskować do Rady Państwa o odwołanie sędziego z przyczyn politycznych, niedawania rękojmi należytego wy-

1 Zob. M. Stanowska, A. Strzembosz, Sędziowie warszawscy w czasie próby 1981-1988, Warszawa 2005, s. 47-52; Wreszcie partner - rozmowa z przedstawicielami NSZZ Pracowników Wymiaru Sprawiedliwości, "Gazeta Prawnicza” (dalej: GP) 1981, nr 7-8, s. 8; Problemów jest mnóstwo - rozmowa z członkami Krajowej Komisji Koordynacyjnej NSZZ „Solidarność” Pracowników Wymiaru Sprawiedliwości, GP 1981, nr 9, s. 4; "Solidarność” pracowników wymiaru sprawiedliwości - rozmowa Jolanty Strzeleckiej z sędzią Adamem Strzemboszem, „Tygodnik Solidarność” (dalej: TS) 1981, nr 10, s. 10; K. Kauba, "Solidarnośćc w resorcie sprawiedliwości, TS 1981, nr 24, s. 14; Informacja Wydziału Administracyjnego KC PZPR z 2 III 1981 r. o sytuacji w ruchu zwiazkowym w resorcie sprawiedliwości, Archiwum Akt Nowych w Warszawie (dalej: AAN), 1354 Polska Zjednoczona Partia Robotnicza. Komitet Centralny (dalej: 1354 KC PZPR), Wydział Administracyjny KC PZPR (dalej: WA), sygn. LI/22, k. 1-8; R. Walczak, Sprawowanie kierowniczej roli partii w sadach i prokuraturze $w$ Polsce Ludowej (studium politologiczne), Warszawa 1987, s. 289-290; J. Szarycz, Sędziowie i sady w Polsce w latach 1918-1988, Warszawa 1988, s. 176. 
konywania obowiązków. Od tego wniosku nie przysługiwały sędziom środki odwoławcze, ani obrony przed zarzutami. Minister sprawiedliwości i prezesi sądów decydowali o awansach oraz sprawach płacowych i socjalnych sędziów. Prezesi SW prowadzili nabór aplikantów i nadzorowali przebieg aplikacji sądowej. W ramach sprawowanego nadzoru sądowego minister sprawiedliwości i prezesi sądów mieli możliwość wglądu do akt toczących się spraw, wskazywania sędziom uchybień i żądania ich usunięcia. Sędziowie nie mieli możliwości wniesienia sprzeciwu od wytyków nadzoru administracyjnego ${ }^{2}$. Przy podejmowaniu decyzji minister sprawiedliwości i prezesi sądów musieli liczyć się jedynie z opinią i wytycznymi właściwych instancji PZPR. Wymiar sprawiedliwości znajdował się pod nadzorem politycznym wydziałów administracyjnych Komitetu Centralnego i komitetów wojewódzkich PZPR ${ }^{3}$.

Sędziowie byli pozbawieni możliwości wpływania na sprawy swego środowiska. Samorząd sędziowski miał jedynie charakter „teoretyczny (...) i w ogóle nie zasługiwał na miano samorządu" ${ }^{4}$. Zgromadzenia ogólne sędziów Sądu Najwyższego (SN) i SW były pozbawione kompetencji merytorycznych. Ich rola ograniczała się do wyboru połowy składów kolegiów administracyjnych i pełnych składów sądów dyscyplinarnych w SN i SW. Kolegia administracyjne decydowały $w$ istotnych sprawach podziału czynności w sądach. Były to jednak, zgodnie z ich nazwą, organy podległe prezesom SW i SN, którzy im przewodniczyli i decydowali o obsadzie połowy składu kolegiów. Sądy dyscyplinarne działały zaś wyłącznie na wniosek organów nadzoru administracyjnego. W tak iluzorycznej samorządności w ogóle nie partycypowali sędziowie sądów rejonowych.

Posierpniowa sytuacja społeczno-polityczna w kraju pozwoliła sędziom upomnieć się o przynależną ich zawodowi samorządność. Domagali się oni w tym zakresie:

a) przekształcenia zgromadzeń ogólnych sędziów SW w zgromadzenia okręgów SW przez dopuszczenie do tego organu również sędziów SR lub wybranych delegatów SR;

2 Zob. przepisy ustawy z dnia 15 lutego 1962 r. o Sądzie Najwyższym (Dz. U. Nr 11, poz. 54 ze zm.) oraz obowiązującego wówczas z gruntownymi zmianami rozporządzenia Prezydenta Rzeczypospolitej Polskiej z dnia 6 lutego 1928 r. - Prawo o ustroju sądów powszechnych (Dz. U. z 1964 r. Nr 6, poz. 40 ze zm.). Zob. też. A. Rzepliński, Sądownictwo w PRL, Londyn 1990, s. 66-73 i 77-85; R. Walczak, Polityka, sądy, prokuratura, Warszawa 1990, s. 6-32; S. Włodyka, Organizacja wymiaru sprawiedliwości w PRL, Warszawa 1963; Sąd Najwyższy w PRL, red. M. Rybicki, Wrocław 1983, s. 109-136.

3 Zakres pracy Wydziału Administracyjnego KC PZPR, AAN, 1354 KC PZPR, WA, sygn. LI/37 [brak numeracji porządkowej kart w teczce]; Wykaz jednostek objętych nadzorem wydziałów administracyjnych KW PZPR, AAN, 1354 KC PZPR, WA, sygn. LI/43 [brak numeracji porządkowej kart w teczce].

4 S. Rudnicki, O praworządności i niepraworządności w wymiarze sprawiedliwości, „Tygodnik Powszechny" (dalej: TP) 1981, nr 24, s. 5. 
b) przekształcenia kolegiów administracyjnych SW w kolegia sędziowskie okręgów SW, których pełny skład wybierany byłby przez zgromadzenia ogólne sędziów;

c) przyznania tak ukształtowanym organom samorządowym kompetencji w zakresie:

- wysuwania i wyboru kandydatów na stanowiska prezesów i wiceprezesów sądów,

- wysuwania lub opiniowania kandydatów na stanowiska sędziowskiego i asesorskie,

- decydowania o przyjęciu kandydatów na aplikację sędziowską,

- aprobowania lub odrzucania zgłaszanych przez ministra sprawiedliwości wniosków o odwołanie sędziego z przyczyn niedawania rękojmi należytego wykonywania obowiązków,

- wytyczania ogólnych kierunków pracy pozaorzeczniczej sądów,

- decydowania lub wydawania opinii w sprawach przyznawania sędziom podwyżek płac, świadczeń socjalnych, nagród i awansów,

- rozpoznawania odwołań sędziów od wytyków wydawanych w trybie nadzoru sądowego.

Środowisko sędziowskie domagało się ponadto przeprowadzenia do końca marca 1981 r. pozaustawowej weryfikacji urzędujących prezesów sądów, na zasadach wyłaniania kandydatów na te stanowiska przez Zgromadzenia Ogólne Sędziów.

Postulaty te zostały zaadaptowane do programów NSZZ "S" PWS i NSZZ PWS. W listopadzie 1980 r. z postulatami samorządowymi, a także postulatami w zakresie spraw płacowych i socjalnych ${ }^{5}$, władze obydwu związków, odrębnie, wystąpiły do ministra sprawiedliwości. Domagały się przyjęcia przez kierownictwo resortu zobowiązań ich realizacji na drodze umowy, na wzór porozumień sierpniowych.

\section{Konsultacje resortowe w sprawie samorządu sędziowskiego}

Ministerstwo Sprawiedliwości prowadziło od końca listopada 1980 r. równoległe negocjacje z władzami NSZZ "S" PWS i NSZZ PWS w sprawie porozumień. Sporna między stronami była m.in. sprawa samorządu sędziow-

5 Zob. Obywatelskie Centrum Inicjatyw Ustawodawczych Solidarności 1980-1990, oprac. K. Barczyk, S. Grodziski, S. Grzybowski, Warszawa 2001, s. 11; Tezy NSZZ Pracowników Wymiaru Sprawiedliwości w sprawie samorządności sędziowskiej, AAN, 285 Ministerstwo Sprawiedliwości (dalej: 285 MS), sygn. 7/280, k. 53-54; Katalog zagadnień do porozumienia z Ministrem Sprawiedliwości w opracowaniu Krajowej Komisji Koordynacyjnej NSZZ "Solidarnośćc Pracowników Wymiaru Sprawiedliwości, AAN, 285 MS, sygn. 7/176, k. 6-18; Projekt protokołu porozumienia Ministra Sprawiedliwości z Prezydium Komitetu Założycielskiego NSZZ Pracowników Wymiaru Sprawiedliwości, AAN, 285 MS, sygn. 7/280, k. $72-75$. 
skiego ${ }^{6}$, która została poddana pod opinię prezesów SW i OSPiUS 2 grudnia 1980 r. Powołany wówczas zespół opiniodawczy ${ }^{7}$ odrzucił możliwość ustępstw w kierunku zobowiązania się przez ministra sprawiedliwości do przeforsowywania zmian ustawowych $\mathrm{w}$ zakresie rozszerzenia kompetencji samorządu sędziowskiego. Zdaniem zespołu prerogatywy przysługujące $\mathrm{z}$ mocy prawa o ustroju sądów powszechnych kierownictwu resortu i administracji sądowej stanowiły nienaruszalne podstawy funkcjonowania socjalistycznego sądownictwa. W opinii zespołu istniejące organy samorządowe powinny były zostać wyposażone jedynie w kompetencje konsultacyjne. Ponadto, zespół wystąpił przeciwko postulatom dokonania weryfikacji prezesów sądów przez środowisko sędziowskie, powołując się na systematyczną ocenę ich pracy przeprowadzaną przez resort sprawiedliwości ${ }^{8}$.

Dalsze konsultacje miały miejsce na konferencji resortowej 15 stycznia 1981 r. Przedstawiciele administracyjnego kierownictwa skrytykowali ponownie koncepcje ograniczenia kompetencji ministra sprawiedliwości i własnych na rzecz samorządu sędziowskiego oraz dokonywania wyboru kandydatów na prezesów sądów przez zgromadzenia ogólne sędziów. Prezes SW w Warszawie Stanisław Pawela podkreślał, iż sądy reprezentowały interes państwowy, co jego zdaniem wykluczało możliwość ingerowania w kompetencje ministra sprawiedliwości przez samorząd sędziowski. Stanisław Pawela uważał, iż koncepcje związkowe uzależnienia kadry kierowniczej sądów od samorządu miało jedynie „na celu sianie niepokoju w sądownictwie". Prezes SW w Bydgoszczy Marian Szabela podkreślał, iż koncepcje samorządu sędziowskiego prezentowane przez związkowców mogły „tylko obniżyć poziom sądownictwa”. Jeden z prezesów - nazwiska nie wpisano do protokołu - postulował zaś przeprowadzenie weryfikacji sędziów i rozszerzenie kompetencji prezesów w zakresie manipulowania kadrą sędziowską9.

W dniu 4 lutego 1981 r., kierownictwo Ministerstwa Sprawiedliwości postanowiło dopuścić do głosu w sprawie sędziów - członków kolegiów administracyjnych SW. Nie było wówczas sporu co do potrzeby urzeczywistnienia struktur i rozszerzenia kompetencji samorządu sędziowskiego. Wprowadzenie w życie idei samorządu - zdaniem prezesa SW w Koszalinie Tadeusza Goź-

Zagadnienia sporne w negocjacjach ze związkami zawodowymi, AAN, 285 MS, sygn. 7/282, k. 124-125.

7 W skład zespołu weszli: Romuald Soroko - prezes SW w Nowym Sączu, Jan Blat - prezes SW w Tarnowie, Kazimierz Michaluk - prezes OSPiUS w Warszawie, Jędrzej Witkowski - prezes SW w Gdańsku, Jan Zając - prezes SW w Kielcach, Edward Kapłon - prezes OSPiUS w Krakowie, a także z ramienia resortu: Eugeniusz Lipiński - sekretarz zespołu i Jerzy Kosiński - wicedyrektor Departamentu Kadr.

8 Opinia co do możliwości rozszerzenia samorządu sędziowskiego, AAN, 285 MS, sygn. 7/280, k. 55-56 i 63-64.

9 Protokót z konferencji prezesów SW i OSPiUS w dniu 15 I 1981 r., AAN, 285 MS, sygn. 7/179, k. 10, 12 i 14. 
dzickiego - zwiększyłoby bowiem odpowiedzialność kolektywów sędziowskich za całokształt pracy sądów i mogłoby w rzeczywistości być istotnym wsparciem dla kierownictwa. Podstawą urealnienia struktur samorządowych zdaniem zebranych - było przekształcenie kolegiów administracyjnych, w kolegia sędziowskie, którym przewodniczyłby prezes SW. W opinii większości organy samorządowe powinny były mieć jednak charakter organów o kompetencjach konsultacyjno-opiniodawczych $\mathrm{w}$ zakresie kształtowania polityki kadrowej, w sprawach socjalnych i płacowych sędziów. Sfera decyzyjna powinna była pozostać $w$ rękach ministra sprawiedliwości i prezesów. Sędzia SW w Kielcach Andrzej Wypiórkiewicz wskazywał, iż samorząd sędziowski powinien był „znaleźć dla siebie miejsce gdzieś w obszarach pomiędzy inicjowaniem, opiniowaniem a kontrolowaniem, (...) w punktach wejścia i wyjścia", nie mógł jednak zastąpić administracji sądowej.

Prezesów i sędziów poróżniła sprawa weryfikacji kadr kierowniczych sądów z udziałem zgromadzeń ogólnych sędziów. Nie negowano potrzeby jej dokonania, nie było jednak jednolitości poglądów co do charakteru uczestnictwa w tym procesie środowiska sędziowskiego. Prezes SR dla Krakowa-Śródmieście Gustaw Wróbel wskazywał, iż kompetencje samorządu powinny były ograniczać się do opiniowania kandydatów. Opowiadał się on przeciwko wyborom prezesów przez sędziów. Zdaniem prezesa Goździckiego, proponowane typowanie kandydatów przez zgromadzenia ogólne prowadziłoby do wybieralności prezesów przez sędziów, co - jego zdaniem - było niedopuszczalne, naruszałoby bowiem uprawnienia ministra sprawiedliwości i zasadę nomenklatury partyjnej, w której pozostawały stanowiska prezesów. Odmienne opinie wyrażali sędziowie - członkowie kolegiów. Sędzia z Gdańska Barbara Multan opowiadała się za przyjęciem rozwiązań proponowanych przez związkowców. O krok dalej szedł sędzia ze Szczecina Mieczysław Daca. Uważał on, iż prezesi powinni byli być wybierani przez Zgromadzenia Ogólne. Uprawnienia ministra sprawiedliwości powinny zaś ograniczać się do możliwości złożenia sprzeciwu do Sądu Najwyższego. Sędzia Włodzimierz Olszewski z Krakowa odnosząc się do wypowiedzi prezesa Goździckiego, podkreślał z kolei, iż „zdaniem tego prezesa (...) typowanie prezesów przez zgromadzenia ogólne naruszałoby upoważnienie Ministra Sprawiedliwości i nomenklaturę partyjną. Myślę, że przy najdalej posuniętej samorządności, minister sprawiedliwości jest w stanie poradzić sobie z wyegzekwowaniem obowiązków ciążących na sędziach, a jeśli chodzi o nomenklaturę partyjną to nic nie stracimy, jeżeli odejdziemy od tego systemu"10.

Prezesi sądów podchodzili wrogo do idei samorządu sędziowskiego, która wiązała się z ograniczeniem ich kompetencji. Widoczne były animozje między środowiskiem sędziowskim a kierownictwem administracyjnym sądów. Wy-

10 Protokół z konferencji resortowej w dniu 4 II 1981 r., AAN, 285 MS, sygn. 7/180, k. 9-15 i 19. 
zbycie się prawa powoływania połowy składu kolegiów administracyjnych na rzecz zgromadzenia sędziów była jedyną prerogatywą, z której prezesi byli skłonni zrezygnować. Dostrzegali oni również możliwość zasięgania opinii organów samorządowych przed podjęciem decyzji w sprawach sędziów.

\section{Sprawa samorządu sędziowskiego w porozumieniu Ministra Sprawiedliwości z NSZZ Pracowników Wymiaru Sprawiedliwości z dnia 11 lutego 1981 r.}

Ministerstwo Sprawiedliwości nie miało sił i środków, pozbawione po sierpniu 1980 r. wsparcia politycznego ze strony władz PZPR, aby przeciwstawić się postulatom środowiska sędziowskiego. To jednak, choć jednomyślnie opowiadające się za potrzebą stworzenia samorządu sędziowskiego, było podzielone na dwa obozy związkowe. Między władzami NSZZ „S" PWS a NSZZ PWS istniała wzajemna nieufność, nie występowały one wspólnie $w$ obronie postulatów samorządowych. Pozwoliło to Ministerstwu Sprawiedliwości zerwać w połowie grudnia $1980 \mathrm{r}$. negocjacje $\mathrm{z}$ bezkompromisową $\mathrm{w}$ sprawach samorządu i gwarancji dla niezawisłości sędziowskiej sądową „Solidarnością"11. Władze założycielskie NSZZ PWS były zaś gotowe do ustępstw. Autonomistom zależało bowiem na załatwieniu spraw poprawy warunków płacy, pracy i socjalno-bytowych pracowników wymiaru sprawiedliwości.

Do zawarcia porozumienia między NSZZ PWS a ministrem sprawiedliwości doszło w dniu 11 lutego $1981 \mathrm{r}$. W rozdziale II porozumienie ${ }^{12}$ nakładało na ministra sprawiedliwości obowiązek powołania $\mathrm{w}$ terminie dwóch tygodni resortowo-związkowego zespołu ekspertów celem określenia kompetencji i form działania przyszłych struktur samorządu sędziowskiego. W pracach zespołu mieli uczestniczyć w połowie przedstawiciele resortu i funkcjonujących w sądach związków zawodowych. Porozumienie zakładało opracowanie przez zespół w terminie trzech miesięcy rozwiązań, które miały stać się podstawą nowelizacji prawa o ustroju sądów powszechnych. Zarysowano również ogólne zasady rozszerzenia samorządności sędziowskiej, którymi kierować się miał zespół ekspertów. Należały do nich zasady: zwiększenia kompetencji zgromadzenia ogólnego sędziów; rozszerzenia składu Zgromadzenia Ogólnego o sędziów sądów rejonowych; zapewnienia udziału sędziów rejonowych w składach orzekających sądów dyscyplinarnych w sprawach dotyczących sędziów tych sądów oraz sędziów sądów wojewódzkich w składach wyższego sądu dyscyplinarnego; utworzenia kolegiów sędziowskich w miejsce kolegiów ad-

11 Notatka o przebiegu rozmów z "Solidarnościa" - 11 i 12 XII 1980 r., AAN, MS 285, sygn. 7/114, k. 27.

12 Protokót porozumienia Ministra Sprawiedliwości z NSZZ Pracowników Wymiaru Sprawiedliwości w sprawie realizacji postulatów pracowniczych, GP 1981, nr 5-6, s. 6. 
ministracyjnych z równoczesnym rozszerzeniem ich kompetencji; zapewnienia realnego wpływu Zgromadzenia Ogólnego sędziów na obsadzanie stanowisk prezesów i wiceprezesów sądów; wprowadzenia zasady kadencyjności na stanowisku prezesa; zapewnienia samorządowi sędziowskiemu wpływu na powoływanie sędziów SW i SR, asesorów i aplikantów oraz wpływu na politykę wynagradzania i awansową.

Minister sprawiedliwości zobowiązał się również do wcześniejszego, pozaustawowego rozszerzenia kompetencji organów samorządu sędziowskiego przez umożliwienie zgromadzeniom ogólnym SW dokonywania wyboru wszystkich członków kolegiów administracyjnych, wypowiadania się co do podstawowych kierunków pracy sądownictwa w danym okręgu, wypowiadania się $\mathrm{w}$ przedmiocie zagadnień kadrowych i płacowych okręgu, opiniowania składu kadry rezerwowej oraz ustalania kierunków działalności pozaorzeczniczej sądów, opiniowania kandydatów na stanowiska prezesów i wiceprezesów sądów wojewódzkich i sądów rejonowych.

Porozumienie $\mathrm{w}$ takim kształcie satysfakcjonowało kierownictwo resortu sprawiedliwości. Sprawa samorządu sędziowskiego została odroczona. Zasady, na których miały się opierać przyszłe rozwiązania ustawowe - co podkreślała w ocenie porozumienia KKK NSZZ "S" PWS - zostały sformułowane w sposób ogólnikowy, dawały pole do swobodnej ich interpretacji i mogły się stać przyczyną dalszych konfliktów ${ }^{13}$. Przyjęte zaś przez ministra sprawiedliwości Jerzego Bafię zobowiązania do pozaustawowego rozszerzenia kompetencji zgromadzeń ogólnych ograniczały się do przyznania im roli opiniodawczej. Niemniej jednak porozumienie było osiągnięciem związku autonomicznego. Zawierało zobowiązania, które stały się przedmiotem nacisku ze strony związkowców. Dokładnie określono terminy ich realizacji. Porozumienie $\mathrm{w}$ ten sposób nadało faktyczny bieg ministerialnym pracom nad stworzeniem projektów nowelizacji prawa o ustroju sądów powszechnych w zakresie rozszerzenia samorządności sędziowskiej i zapewniało aktywny udział związkowców w tych pracach.

\section{Koncepcja samorządu sędziowskiego w pracach zespołu resortowo-związkowego}

Z początkiem marca $1981 \mathrm{r}$. Ministerstwo Sprawiedliwości przystąpiło do realizacji zobowiązań zawartych $\mathrm{w}$ porozumieniu z NSZZ PWS. Powołany został zespół resortowo-związkowy ${ }^{14}$, który składał się z 26 osób w połowie po-

13 Pismo z 8 II 1981 r. KKK NSZZ „S" PWS do Ministra Sprawiedliwości, AAN, 285 MS, sygn. 7/274, k. 208

14 Ocena realizacji porozumień zawartych w resorcie sprawiedliwości, AAN, MS 285, sygn. 7/13, k. 35-42. 
wołanych przez kierownictwo resortu, a w połowie przez związki zawodowe. Jego przewodniczącym został wiceprezes SW w Olsztynie, poseł na Sejm PRL VIII kadencji z ramienia SD, sędzia Szczepan Styranowski. W pracach zespołu uczestniczyli wyłącznie przedstawiciele NSZZ PWS i reaktywowanego w marcu 1981 r. Związku Zawodowego Pracowników Państwowych i Społecznych, którego rola była jednak marginalna. NSZZ "S" PWS zrezygnowała z partycypacji w pracach resortowych i podjęła się opracowania własnych projektów nowelizacji prawa o ustroju sądów powszechnych i ustawy o Sądzie Najwyższym, w ramach działalności powołanego 17 stycznia 1981 r. przy NSZZ "Solidarność" Centrum Obywatelskich Inicjatyw Ustawodawczych ${ }^{15}$. Sędziowie "Solidarności" prezentowali problematykę samorządu sędziowskiego również $\mathrm{w}$ prasie, szukając społecznego poparcia dla tych postulatów ${ }^{16}$.

Zespół resortowo-związkowy przygotował założenia samorządu sędziowskiego w kwietniu $1981 \mathrm{r}$. W myśl tych założeń, podstawowymi organami samorządu miały być zgromadzenia ogólne okręgów SW oraz wybierane w pełnym składzie przez zgromadzenia kolegia sędziowskie i sądy dyscyplinarne. W skład zgromadzeń ogólnych mieli wchodzić sędziowie rejonowi. Kolegia sędziowskie miały składać się z sędziów SW, w co najmniej połowie składu, i sędziów SR. W założeniach zespołu prezesi SW mieli zostać pozbawieni prawa przewodniczenia kolegiom. Wśród założeń po raz pierwszy pojawiła się ponadto koncepcja utworzenia krajowej reprezentacji samorządu w postaci zgromadzenia przewodniczących kolegiów sędziowskich, które miało wyrażać opinie $\mathrm{w}$ istotnych sprawach wymiaru sprawiedliwości oraz dotyczących interesów zawodowych ogółu sędziów.

W dyskusji wróciła koncepcja wyboru przez zgromadzenia ogólne kandydatów na prezesów SW, których zgłaszać mieli minister sprawiedliwości i sędziowie danego okręgu. Alternatywnie zespół proponował przyznać wyłączne prawo wysuwania kandydatów na prezesów ministrowi sprawiedliwości, Zgromadzeniu Ogólnemu zaś prawo sprzeciwu. Nie określono jednak, jakie skutki miałby wywierać sprzeciw środowiska sędziowskiego. Założenia przewidywały wprowadzenie trzyletniej kadencji na stanowiskach prezesów i wiceprezesów.

Nie były klarowne koncepcje zespołu w zakresie przyznania kolegium sędziowskiemu szerszych kompetencji do kreowania polityki kadrowej w sądach. Zespół opowiadał się za wypracowaniem rozwiązań pozwalających kolegium współdecydować wraz z prezesem SW o przedstawianiu ministrowi sprawie-

15 Obywatelskie Centrum Inicjatyw..., s. 93-106, 113-124.

16 J. Ślężak, Dlaczego polskie sq̨downictwo powinno być samorząne?, TS 1981, nr 11, s. 12-13; A. Strzembosz, O samorzadne sądownictwo w samorzadnej Rzeczypospolitej, TS 1981, nr 33, s. 13; S. Rudnicki, O praworządności i niepraworządności w wymiarze sprawiedliwości, TP 1981, nr 24, s. 5; A. Strzembosz, „Solidarność" o prawie i praworządności, GP 1981, nr 15-16, s. 5. 
dliwości kandydatów na asesorów, sędziów oraz wiceprezesów. Nie określono, jakie formy miałaby przybrać ta współpraca. Ponadto, kolegia miały zatwierdzać kandydatów na aplikantów sądowych, wypowiadać się w sprawach stosunku służbowego sędziów oraz, co stanowiło również ważne novum, opiniować pochodzących z danego okręgu kandydatów na sędziów SN i Naczelnego Sądu Administracyjnego (NSA) ${ }^{17}$.

Wypracowane koncepcje $\mathrm{w}$ większości odpowiadały postulowanym przez środowisko sędziowskie zmianom. Widoczne były próby uzyskania kompromisowych rozwiązań w najbardziej spornych kwestiach. Sprawa konfliktu kompetencyjnego między prezesami sądów a przyszłym samorządem pozostawała jednak wciąż nierozstrzygnięta. Zespół wniósł też nowe, niezwykle istotne koncepcje, przede wszystkim stworzenia krajowej reprezentacji samorządu sędziowskiego.

\section{Resortowa koncepcja ograniczenia wpływu terenowych instancji PZPR na kształtowanie polityki kadrowej w sądach}

12 czerwca 1981 r. doszło do zmiany na stanowisku ministra sprawiedliwości, na którym J. Bafię zastąpił prezes NSA Sylwester Zawadzki. Nie przyniosła ona oczekiwanych przez PZPR zmian w kierunku zaostrzenia polityki resortu wobec związków zawodowych w sądownictwie, lecz niepokojące dla władz partyjnych tendencje reformatorskie, zapoczątkowane paradoksalnie wystąpieniem resortowej podstawowej organizacji partyjnej (POP).

20 czerwca 1981 r. do Kolegium Ministerstwa Sprawiedliwości trafiły wnioski POP PZPR w sprawach samorządu sędziowskiego i polityki kadrowej $\mathrm{w}$ sądach. Krytyce poddane zostały w nich zasady obsady stanowisk prezesów i sędziów. „Kryzys praworządności i krytyczna ocena społeczna wymiaru sprawiedliwości, wyrażana w ostatnich miesiącach, rzutuje" - wskazywało POP PZPR - „na krytyczną ocenę kadr organów wymiaru sprawiedliwości i polityki kadrowej kreowanej przez ośrodki decyzyjne w Partii i w administracji wymiaru sprawiedliwości. (...) Niewłaściwa polityka kadrowa w obsadzaniu stanowisk prezesów sądów rejonowych i wojewódzkich doprowadziła w wielu sądach do konfliktów, niewłaściwej atmosfery pracy i radykalizowania się poglądów i postulatów pracowników. Nie zostały stworzone wystarczające mechanizmy chroniące niezawisłość sędziowską przed ingerencją za strony funkcjonariuszy organów partyjnych i administracyjnych, mechanizmy sprzyjające właściwemu naborowi na aplikację sądową („,konkurs znajomości") i asesurę, a także mechanizmy sprzyjające sprawiedliwym awan-

17 Postulaty posierpniowe w resorcie sprawiedliwości - informacja Ministerstwa Sprawiedliwości o ich realizacji z kwietnia 1981 r., AAN, MS 285, sygn. 7/274, k. 234-236. 
som w zawodzie (brak jasno sprecyzowanych kryteriów awansu) i wyróżnieniom (odznaczenia, nagrody). Wydaje się, że w dotychczasowej praktyce wysuwania na kierownicze stanowiska nadmierną wagę przywiązywano do przynależności sędziów i niektórych innych pracowników resortu do PZPR. (...) Krytycznie należy ocenić też praktykę preferowania ludzi uległych i niesamodzielnych. U źródeł powszechnego i słusznego żądania odrodzenia samorządności sędziowskiej leżą nieprawidłowości polityki kadrowej, wadliwe korzystanie przez organy partyjne $\mathrm{z}$ prerogatyw płynących $\mathrm{z}$ tzw. nomenklatury oraz słaba orientacja centrali resortu $\mathrm{w}$ problemach terenowych jednostek organizacyjnych. (...) Nieprawidłowości w polityce kadrowej w resorcie są tak poważne a dążenia do samorządności tak duże, że naczelną gwarancją uzdrowienia polityki kadrowej $\mathrm{w}$ sądach pozostaje przyznanie szerokich kompetencji samorządom sędziowskim w zakresie współdecydowania o obsadzaniu stanowisk prezesów sądów. Zespół opowiada się jednocześnie za ograniczeniem nomenklatury partyjnej do kluczowych stanowisk w resorcie sprawiedliwości"18.

Problemy samorządu sędziowskiego i polityki kadrowej, pod wpływem wystąpienia resortowej POP PZPR, stały się głównym temat konferencji resortowej z udziałem prezesów SW i OSPiUS, która miała miejsce 7 lipca 1981 r. Minister Zawadzki podkreślał wówczas szczególne znaczenie sprawnego wywiązywania się z zobowiązań wynikających z lutowego porozumienia z NSZZ PWS. Przedstawił on zakres prowadzonych przez resort prac nad stworzeniem nowego modelu sądownictwa $w$ ramach nowelizacji prawa o ustroju sądów powszechnych, w którym ważne miejsce miały zająć kwestie związane z rozszerzeniem kompetencji samorządu sędziowskiego. "Obecnie samorząd sędziowski ma raczej charakter fasadowy" - wskazywał S. Zawadzki - „podniesienie roli samorządu to przede wszystkim zapewnienie realnego wpływu samorządu na stanowiska kierownicze, przyjęcie przez samorząd współodpowiedzialności za poziom pracy sędziów. Jednym z najpilniejszych problemów w tym kompleksie zagadnień jest znalezienie właściwej klauzuli dotyczącej współdecydowania o obsadzie stanowisk kierowniczych $\mathrm{w}$ sądownictwie $w$ trójkącie, minister sprawiedliwości - samorząd sędziowski - instancje partyjne. Ta cecha nowego modelu sądownictwa wiąże się zarówno z ugruntowaniem zasady niezawisłości sędziowskiej, jak również z nowym podejściem do realizacji przewodniej roli partii w sferze wymiaru sprawiedliwości". W dalszej części wypowiedzi minister Zawadzki wskazywał, iż prawidłowo ukształtowany i funkcjonujący samorząd byłby jednym z gwarantów konstytucyjnej zasady niezawisłości sędziowskiej. ,Jest rzeczą niezmiernie ważną, aby kompetencje i zakres działania organów samorządu zostały określone w taki sposób,

18 Protokót z posiedzenia Kolegium Ministerstwa Sprawiedliwości w dniu 20 VI 1981 r., AAN, 285 MS, sygn. $7 / 125$, k. 20-23. 
aby $\mathrm{z}$ jednej strony zapewniały środowisku sędziowskiemu realny wpływ na funkcjonowanie sądownictwa, $\mathrm{z}$ drugiej zaś zabezpieczały przed partykularyzmem oraz stwarzały warunki dla realizowania polityki ogólnospołecznej" wskazywał minister Zawadzki - „rozbudowując samorządność, pamiętać bowiem musimy, że sądy, będące organami państwa, realizują określone cele ogólnospołeczne, co z kolei wymaga jednolitej polityki orzeczniczej i sprężystego kierownictwa"19.

Z wypowiedzi tej nie wynikało w sposób jednoznaczny, jaki ostatecznie zakres kompetencji samorządu zaproponuje resort. Minister Zawadzki wskazał jednak, iż nie mogły one ograniczać możliwości wpływania na politykę orzeczniczą sądów ze strony administracji sądowej. Interesująca była zapowiedź opracowania nowego modelu przewodnictwa PZPR w sferze wymiaru sprawiedliwości. Dyskusja wśród prezesów sądów na lipcowej konferencji pokazała, iż w resorcie zwiększało się poparcie dla koncepcji uniezależnienia sądownictwa od terenowych instancji PZPR. Prezesi również wskazywali na destrukcyjny wpływ ingerencji KW PZPR na kształtowanie polityki kadrowej w sądach. Zdaniem prezesa OSPiUS w Opolu Waldemara Mygi, powinna była ona znajdować się w wyłącznej kompetencji ministra sprawiedliwości, „który za prowadzoną politykę kadrową ponosi odpowiedzialność polityczną. Partia obsadzając stanowisko Ministra Sprawiedliwości powinna zaufać, że będzie on prowadził politykę kadrową zgodną z polityką partii i zasadami ustrojowymi". Pozostałą po KW PZPR „lukę" powinny były - zdaniem W. Mygi - wypełnić zakładowe organizacje partyjne $\mathrm{w}$ sądach, które opiniowałyby pracowników sądownictwa pod kątem politycznym. Na zakończenie dyskusji ponownie zabrał głos minister Zawadzki, który „podkreślił związek między realizowaniem zasady przewodniej roli partii $\mathrm{w}$ stosunku do sądów z zasadą niezawisłości sędziowskiej. Tę drugą zasadę należy traktować nie tylko jako jedną z zasad wymiaru sprawiedliwości, ale także jako jedną z zasad dotyczących realizacji przewodniej roli partii" ${ }^{20}$. Minister Zawadzki argumentował dodatkowo na kolejnej, wrześniowej konferencji prezesów w Popowie, iż „zabezpieczenie sądów przed nadmiernymi wpływami lokalnymi przyczyniłoby się $\mathrm{w}$ konsekwencji do większej jednolitości polityki orzeczniczej"21.

Resort dążył więc do uzyskania większej samodzielności w podejmowaniu decyzji $w$ zakresie funkcjonowania sądów, $\mathrm{z}$ przyjęciem zasady rozliczenia ministra sprawiedliwości przez KC PZPR za efekty realizacji polityki partii przez

19 Zadania resortu sprawiedliwości w świetle aktualnej sytuacji społeczno-politycznej kraju, AAN, 285 MS, sygn. 7/182, k. 64-65 i 82.

20 Protokót z konferencji resortowej w dniu $7 V 1981$ r., AAN, 285 MS, sygn. 7/182, k. 14, 16, 21-22 i 31-32.

21 Wystapienie Ministra Sprawiedliwości prof. Sylwestra Zawadzkiego na konferencji prezesów SW i OSPiUS (Popowo 18-19 IX 1981 r.), AAN, 285 MS, sygn. 7/183, k. 8. 
prezesów sądów i sędziów. Dostrzegano przy tym potrzebę przyznania organom samorządu sędziowskiego kompetencji konsultacyjnych, co służyłoby integracji resortu i prezesów ze środowiskiem sędziowskim.

\section{Samorząd sędziowski w resortowym projekcie nowelizacji prawa o ustroju sądów powszechnych z 24 listopada 1981 r.}

Latem 1981 r., pod nadzorem wiceministra sprawiedliwości Tadeusza Skóry i podsekretarz stanu w Ministerstwie Sprawiedliwości Marii Regent-Lechowicz, opracowany został wstępny resortowy projekt nowelizacji prawa o ustroju sądów powszechnych. Sprawa samorządu sędziowskiego została w projekcie zawarta w sposób dwuwariantowy ${ }^{22}$.

Wariant pierwszy stanowił powielenie koncepcji wypracowanych przez zespół resortowo-związkowy wiosną 1981 r. Uzupełniono ją jedynie o precyzyjne określenie zadań kolegiów sędziowskich, do których należeć miało m.in. zatwierdzanie przedstawianych przez prezesów SW podziałów czynności w sądach, zatwierdzanie kandydatów na aplikantów oraz wyłączne prawo przedstawiania zgromadzeniom ogólnym sędziów do wyboru kandydatów na prezesów SW oraz ministrowi sprawiedliwości kandydatów na asesorów i sędziów SR i SW, a także kandydatów na stanowiska wiceprezesów SW, prezesów i wiceprezesów sądów rejonowych.

W drugim wariancie proponowano ograniczenie struktur i kompetencji samorządu sędziowskiego do roli opiniodawczej z zachowaniem nadrzędnej pozycji ministra sprawiedliwości i prezesów sądów wobec środowiska sędziowskiego. Koncepcja ta była zgodna z resortową wizją samorządu sędziowskiego. Nie przewidywała ona wśród organów samorządowych reprezentacji na szczeblu krajowym. Zgromadzeniom ogólnym i kolegiom sędziowskim mieli według tej koncepcji przewodniczyć prezesi sądów wojewódzkich. Uczestnictwo zgromadzeń ogólnych w procesie powoływania na stanowiska prezesów SW miało ograniczać się do dokonywania oceny kandydatów przedstawianych wyłącznie przez Ministra Sprawiedliwości. Kolegia sędziowskie miały z kolei wyrażać jedynie opinie o przedstawianych ministrowi sprawiedliwości przez prezesów SW kandydatach na stanowiska asesorów i sędziów SR i SW oraz wiceprezesów SW, prezesów i wiceprezesów sądów rejonowych.

Nad przyjęciem ostatecznej koncepcji kształtu i kompetencji przyszłego samorządu sędziowskiego kierownictwo resortu dyskutowało 25 września $1981 \mathrm{r}$. $\mathrm{W}$ dokumentach archiwalnych nie zachował się protokół z tego posiedzenia. Istotnych informacji dostarcza jednak notatka służbowa nieznanego autorstwa z 7 października $1981 \mathrm{r}$. Wynika z niej, iż kierownictwo nie zaakceptowało 
wprowadzenia zasady udziału sędziów SR w zgromadzeniach ogólnych, gdyż mogłoby to skutkować zdominowaniem tych organów przez prawie czterokrotnie liczniejsze od sędziów SW grupy sędziów rejonowych. Udział wszystkich sędziów SR - zdaniem kierownictwa resortu - nadawałby ponadto zgromadzeniom charakter sejmików, utrudniający sprawne funkcjonowanie samorządu. W sprawie trybu powoływania prezesów sądów za bardziej wyważoną propozycję kierownictwo MS uznało ograniczenie kompetencji samorządu do opiniowania kandydatów przedstawianych przez ministra sprawiedliwości. Dopuszczało jednocześnie możliwość przedstawiania części kandydatów przez środowisko sędziowskie. Zdaniem kierownictwa tego typu rozwiązanie zapewniałoby realny wpływ samorządu na obsadę stanowisk prezesów, przy tym nie czyniłoby iluzorycznymi kompetencji ministra sprawiedliwości. Prezesi SW mieli przewodniczyć zgromadzeniom ogólnym i kolegiom sędziowskim, celem zapobieżenia przeciwstawieniu organów samorządowych administracji sądowej23.

Projekt nowelizacji prawa o ustroju sądów powszechnych, datowany na 7 listopada, resort przekazał do konsultacji Radzie Naczelnej NSZZ PWS ${ }^{24}$. Władze związku autonomistów wyraziły wówczas pogląd, iż był on "drastycznym odstępstwem od treści zawartego $\mathrm{w}$ dniu 11 lutego $1981 \mathrm{r}$. porozumienia społecznego oraz opracowanych na tej podstawie »założeń funkcjonowania samorządu sędziowskiego « stanowiących jej integralną część. (...) Przygotowany przez resort projekt wraz $\mathrm{z}$ jego uzasadnieniem jest nacechowany nieufnością do środowiska sędziowskiego i niezrozumieniem dążeń tego środowiska do wydźwignięcia polskiego wymiaru sprawiedliwości z głębokiego kryzysu społecznego zaufania w jakim się on znalazł". Treść uchwały RN NSZZ PWS potwierdza, iż z w projekcie nie znalazły się przepisy dotyczące uczestnictwa sędziów SR w zgromadzeniach ogólnych oraz wyboru przez te organy kandydatów na prezesów sądów ${ }^{25}$.

W dniu 24 listopada 1981 r. przygotowana została w resorcie sprawiedliwości ostateczna wersja projektu ustawy o zmianie prawa o ustroju sądów powszechnych, wraz z uzasadnieniem ${ }^{26}$. Kierownictwo resortu sprawiedliwości pozostawiło $w$ nim wiele spornych kwestii wciąż w wersji dwuwariantowej. Ostateczny głos $\mathrm{w}$ tak istotnej sprawie, jak kwestia samorządu sędziowskiego należał bowiem do kierownictwa PZPR.

Notatka w sprawie samorzadu sędziowskiego z dnia 7 X 1981 r., AAN, 285 MS, sygn. 7/283, k. 6-8.

Projektu w wersji z dnia 7 XI 1981 r. nie odnaleziono w dokumentach archiwalnych.

25

Uchwała Rady Naczelnej NSZZ Pracowników Wymiaru Sprawiedliwości z dnia 19 XI 1981 r. w sprawie projektu ustawy o zmianie prawa o ustroju sądów powszechnych, AAN, 285 MS, sygn. 7/283, k. 50-51.

26 Opublikowana ona została nakładem podległego ministerstwu „Wydawnictwa Prawniczego" w grudniu 1981 r., zob. AAN, 285 MS, sygn. 18/148, k. 20-49. 
Organami samorządu - w myśl przepisów projektu z 24 listopada - miały być zgromadzenia ogólne sędziów, kolegia sędziowskie, sądy dyscyplinarne, zebrania sędziów danego sądu, a także krajowa konferencja przedstawicieli zgromadzeń ogólnych.

Nie rozstrzygnięto $\mathrm{w}$ nim ostatecznie kwestii składu i przewodniczenia zgromadzeniom ogólnym. Zachowane zostały dwa warianty rozwiązań. W pierwszym zgromadzenia ogólne miały składać się z sędziów SW i delegatów z SR wybieranych na zebraniach sędziów rejonowych poszczególnych sądów, przy czym liczba delegatów miała nie przekraczać $1 / 3$ bądź, tu również wariantowo, 1/2 liczby sędziów sądów wojewódzkich. Projekt dopuszczał również uczestnictwo $\mathrm{w}$ zgromadzeniach sędziów rejonowych niebędących delegatami oraz asesorów, lecz bez prawa głosowania i wyboru. Zgromadzeniom ogólnym mieli przewodniczyć prezesi SW lub, w drugim wariancie, przewodniczących miały wybierać zgromadzenia spośród sędziów sądów wojewódzkich.

Zgromadzenia ogólne miały zbierać się co najmniej raz w roku. Zwoływać je miały kolegia sędziowskie $\mathrm{z}$ własnej inicjatywy lub na wniosek ministra sprawiedliwości, prezesów SW albo 1/5 sędziów danego okręgu SW. Do zadań zgromadzeń ogólnych miało należeć: wysłuchiwanie informacji prezesów o działalności podległych im sądów i wypowiadanie opinii w tym zakresie, ustalanie liczby i wybór członków kolegiów sędziowskich i ich zastępców, wybór jednego członka Wyższego Sądu Dyscyplinarnego spośród sędziów SW, ustalanie liczby i wybór członków wojewódzkich sądów dyscyplinarnych, przewodniczącego tego sądu i jego zastępców, wyrażanie opinii o kandydatach na prezesów SW, określanie kierunków pracy kolegiów sędziowskich oraz rozpatrywanie sprawozdań z ich działalności, wybór przedstawiciela na krajową konferencję przedstawicieli zgromadzeń ogólnych.

Kolegia sędziowskie, w myśl projektu, miały składać się z sędziów SW oraz sędziów SR w liczbie nie większej niż 1/3 lub 1/2 jego członków. Ustalenie liczebności składu kolegium i wybór wszystkich jego członków i ich zastępców należeć miało do kompetencji zgromadzeń ogólnych. Kolegium sędziowskiemu przewodniczyć miał prezes sądu wojewódzkiego.

Do kompetencji kolegiów sędziowskich miało należeć: zatwierdzanie podziału czynności w SW i SR opartych na projekcie przedstawionym przez prezesa SW, obejmujący także obsadę stanowisk przewodniczących wydziałów, wyrażanie opinii o kandydatach na asesorów sądowych, sędziów SR i SW, wiceprezesów SW oraz prezesów i wiceprezesów SR, zatwierdzanie kandydatów na aplikantów sądowych, współdziałanie z ministrem sprawiedliwości w ustalaniu kandydatów na stanowisko prezesa SW, wydawanie opinii w sprawach dotyczących stosunku służbowego sędziów, wybór zastępcy przewodniczącego kolegium. 
Zgromadzenia ogólne i kolegia sędziowskie miały podejmować uchwały zwykłą większością głosów, przy czym przy podejmowaniu uchwał przez zgromadzenia wymagana miała być obecność co najmniej 2/3 jego członków, a w przypadku kolegiów pełny skład. W razie nieobecności sędziego - członka kolegium, w posiedzeniu miał uczestniczyć jego zastępca w celu zachowania wymaganego quorum. Projekt nie przewidywał przypadków podejmowania uchwał większością kwalifikowaną. Istotne było wśród tych przepisów, iż w przypadku równej liczby głosów o ostatecznym podjęciu bądź odrzuceniu uchwał przez zgromadzenia i kolegia decydować miał głos przewodniczącego, a więc $w$ przypadku kolegium prezesa sądu wojewódzkiego. Równość głosów $\mathrm{w}$ organach samorządu skutkowałaby wówczas przejęciem ich kompetencji przez kierownika administracji sądowej.

Ogólnokrajowa konferencja przedstawicieli zgromadzeń ogólnych SW miała być organem doraźnym, zwoływanym przez ministra sprawiedliwości na wniosek przynajmniej połowy zgromadzeń ogólnych SW, w celu uzyskania opinii środowiska sędziowskiego $\mathrm{w}$ istotnych sprawach wymiaru sprawiedliwości.

Projekt przewidywał uczestnictwo zgromadzeń ogólnych w procedurze powoływania prezesów $S W$, jednak nie spełniał oczekiwań środowiska $\mathrm{z}$ uwagi na ustaloną w nim zasadę wyłącznego prawa przedstawiania pod opinię zgromadzeń ogólnych kandydatów na te stanowisko przez ministra sprawiedliwości. Kandydatury miały być jedynie uzgodnione $\mathrm{z}$ właściwym kolegium sędziowskim. Minister sprawiedliwości dysponowałby również prawem ostatecznego powołania prezesa SW spośród kandydatów, którzy uzyskali poparcie co najmniej połowy obecnego na głosowaniu składu Zgromadzenia Ogólnego. Wiceprezesi SW, prezesi i wiceprezesi SR mieli być zaś powoływani przez ministra sprawiedliwości spośród kandydatów pozytywnie zaopiniowanych przez właściwe kolegium sędziowskie.

Ponadto, z projektu z 24 listopada, w stosunku do wcześniejszych wersji, usunięto istotną $\mathrm{w}$ postulatach związkowych zasadę obowiązku uzyskiwania przez ministra sprawiedliwości zgody właściwego Zgromadzenia Ogólnego do złożenia wniosku o odwołanie przez Radę Państwa sędziego z przyczyn niedawania przez niego rękojmi należytego wykonywania obowiązków. Listopadowy projekt przewidywał jedynie, iż wniosek ministra sprawiedliwości $w$ tej sprawie podlegał opinii właściwego sądu dyscyplinarnego. Nie uzależniał jednak możliwości złożenia wniosku od tej opinii, a więc nawet $\mathrm{w}$ przypadku uznania przez sąd dyscyplinarny wniosku za nieuzasadniony, minister sprawiedliwości mógł przekazać taki wniosek, wraz z opinią sądu dyscyplinarnego, do decyzji Rady Państwa. 


\section{Wybory kandydatów na prezesa Sądu Wojewódzkiego w Warszawie}

Jesienią 1981 r. zacieśniona została współpraca między NSZZ PWS i NSZZ „S" PWS. Władze związkowe zarzucały ministrowi sprawiedliwości celowe opóźnianie realizacji postanowień porozumienia z 11 lutego 1981 r. i niechęć do przeprowadzania żądanej weryfikacji kadr kierowniczych $\mathrm{w}$ sądach, $\mathrm{w}$ trybie pozaustawowym, przy udziale zgromadzeń ogólnych sędziów. We wspólnym oświadczeniu Prezydia obu związków stwierdziły, iż postępowanie ministra sprawiedliwości odbierało mu wiarygodność w oczach środowiska. Związki zaapelowały o urzeczywistnienie idei samorządu sędziowskiego. Zagroziły, iż "dalsze paraliżowanie działań organów samorządowych, godzące $\mathrm{w}$ proces demokratyzacji stosunków społecznych w Polsce, zmusi oba związki do podjęcia statutowych form protestacyjnych". Prezydia apelowały jednocześnie do sędziów o domaganie się przeprowadzenia weryfikacji kadr kierowniczych sądów ${ }^{27}$. Z tymi żądaniami w październiku 1981 r. wystąpili sędziowie sądów okręgu warszawskiego ${ }^{28}$.

Pod wpływem nacisków związkowych Ministerstwo Sprawiedliwości dopuściło w końcu do swoistego „samorządowego eksperymentu” w okręgu SW w Warszawie, który miał służyć - jak twierdziło kierownictwo resortu - sprawdzeniu w praktyce, branych pod uwagę przy opracowywaniu projektu nowelizacji prawa o ustroju sądów powszechnych, rozwiązań w zakresie trybu powoływania prezesów SW przy udziale zgromadzeń ogólnych sędziów ${ }^{29}$. W dniu 17 listopada 1981 r. doszło do wyboru kandydatów na wolne stanowisko Prezesa SW w Warszawie przez zgromadzenie ogólne sędziów sądów okręgu warszawskiego. Relację z tego wydarzenia zdała sędzia Kazimiera Machcewicz na łamach „Tygodnika Solidarność" 30 . Zgodnie z regulaminem przygotowanym przez kierownictwo warszawskiego SW, w porozumieniu ze związkami zawodowymi i Departamentem Kadr Ministerstwa Sprawiedliwości, kandydatów na prezesa SW wysuwać mogli minister sprawiedliwości, organizacje działające na terenie sądu oraz grupa 10 sędziów. Spośród wyłonionych kandydatów, którzy otrzymaliby więcej niż 50\% głosów zgromadzenia ogólnego, ostatecznego wyboru nowego prezesa SW w Warszawie dokonać miał minister sprawiedli-

27 Oświadczenie Prezydium KKK NSZZ „Solidarność” Pracowników Wymiaru Sprawiedliwości i Prezydium RN NSZZ Pracowników Wymiaru Sprawiedliwości z dnia 13 XI 1981 r., AAN, MS 285, sygn. 7/274, k. 291-292.

Zob. pisma z dnia 7 i 12 października podpisane przez sędziów SW w Warszawie, SR w Piasecznie, SR dla Warszawy-Pragi, SR w Pruszkowie [w:] AAN, MS 285, sygn. 7/283, k. 39-47.

29 Ocena sytuacji społeczno-politycznej w wymiarze sprawiedliwości, AAN, 1354 KC PZPR, BP, sygn. V/173, mkf 2999, k. 30.

30 K. Machcewicz, Samorząd sędziowski, TS 1981, nr 36, s. 11; zob. też G. Pomian, Polska "Solidarności”, Paryż 1982, s. 440-446. 
wości. Bezprecedensowy był fakt dopuszczenia tego dnia do udziału w zgromadzeniu przedstawicieli sądów rejonowych. W głosowaniu wzięło udział 241 z 281 sędziów zatrudnionych w okręgu. Większość głosów, spośród 5 zgłoszonych kandydatów, otrzymali: sędzia SN Stanisław Rudnicki, kandydujący z ramienia NSZZ „S" PWS - 188 głosów, wiceprezes SW w Warszawie sędzia Józef Wieczorek, zgłoszony przez grupę sędziów - 165 głosów oraz przewodniczący Wydziału Cywilnego Rewizyjnego SW w Warszawie sędzia Juliusz Suchecki, kandydujący z ramienia POP PZPR - 124 głosy. Kandydaci zgłoszeni przez ministra sprawiedliwości - sędzia SN Ryszard Bodecki i prezes OSPiUS w Warszawie Kazimierz Michaluk - otrzymali odpowiednio 13 i 23 głosy. Na tej podstawie, na stanowisko Prezesa SW w Warszawie ostatecznie powołany został przez ministra sprawiedliwości sędzia Józef Wieczorek.

Plebiscyt warszawski stanowił zwycięstwo długo oczekiwanej w środowisku sędziów samorządności. Było to jednak pojedyncze ustępstwo ze strony PZPR i Ministerstwa Sprawiedliwości oraz ostatni akt działalności niezależnych i samorządnych związków zawodowych w sądownictwie przed wprowadzeniem stanu wojennego.

\section{Zakończenie}

Po wprowadzeniu stanu wojennego 13 grudnia 1981 r. samorządowe dążenia sędziów zostały stłumione. Ministerstwo Sprawiedliwości za ustępliwą politykę wobec związków zawodowych w sądach spotkało się z krytyką sprawującego nadzór nad wymiarem sprawiedliwości Wydziału Administracyjnego KC PZPR, który zarzucił kierownictwu resortu m.in., iż „pod naciskiem władz obu związków działających w Ministerstwie Sprawiedliwości i jego jednostkach organizacyjnych, naruszając obowiązujące przepisy o ustroju sądów powszechnych, wprowadzało w życie ideę samorządu sędziowskiego (...) w imię tzw. »świętego spokoju « spełniało żądania władz NSZZ »Solidarność«. (...) Uleganie żądaniom władz związków zawodowych, podnoszenie ich rangi w sądach, wprowadzanie w życie samorządu sędziowskiego oraz kadencyjności na stanowiska funkcyjne, spowodowało obniżenie dyscypliny służbowej, autorytetu osób pełniących stanowiska funkcyjne, nadzoru służbowego nad jednolitością i prawidłowością orzecznictwa" ${ }^{\prime 31}$.

Postulaty samorządowe sędziów i projekt resortowy nowelizacji prawa o ustroju sądów powszechnych z listopada $1981 \mathrm{r}$. stały się jednak przedmiotem dalszej dyskusji nad kompleksową reformą ustroju sądownictwa w ramach tzw. „,socjalistycznej odnowy kraju”, prowadzonej w latach 1982-1985 pod dyk-

31 Notatka o sytuacji w resorcie wymiaru sprawiedliwości i jego jednostkach organizacyjnych w II pótroczu 1981 r., AAN, 1354 KC PZPR, WA, sygn. LI/133 [brak numeracji porządkowej kart w teczce]. 
tando PZPR. W jej wyniku przyjęto nowe ustawy o Sądzie Najwyższym ${ }^{32}$ i ustroju sądów powszechnych ${ }^{33}$. W sprawach samorządowych doszło do kilku zmian. Do zgromadzeń ogólnych SW dopuszczono sędziów delegatów wybranych na zebraniach sądów rejonowych. Zgromadzeniom przyznano dodatkowo kompetencje w zakresie wydawania opinii dotyczących ogólnej działalności sądów i sędziów danego okręgu oraz określania kierunków prac kolegiów SW. Zmieniono nazwę kolegiów administracyjnych na kolegia SW, nie uległ jednak zmianie sposób powoływania składu tego organu. Nowe kompetencje kolegiów miały charakter wyłącznie konsultacyjny, dotyczyły one opiniowania kandydatów na sędziów i asesorów, ustalania projektu listy kandydatów na aplikację sądową, opiniowania spraw dotyczących stosunku służbowego sędziów. Organy samorządowe nie miały wpływu na powoływanie prezesów sądów ${ }^{34}$.

Zmiany te nie spełniały więc oczekiwań sędziów. Zgromadzenia ogólne wciąż były pozbawione większego wpływu na sprawy własnego środowiska. W kolegiach dominującą pozycję zachowali zaś prezesi sądów wojewódzkich. Organy samorządowe nie miały kompetencji decyzyjnych. W pewnym stopniu zrealizowano jednak koncepcje resortowe quasi-samorządu, o charakterze konsultacyjnym, pozostawiając sferę decyzyjną $\mathrm{w}$ rękach ministra sprawiedliwości i prezesów sądów.

Sędziowskie postulaty z lat 1980-81 doczekały się realizacji w okresie transformacji ustrojowej. Nowelizacją ustawy - Prawo o ustroju sądów powszechnych z dnia 20 grudnia 1989 r. ${ }^{35}$ przekazano do kompetencji zgromadzeń ogólnych sędziów okręgów SW prawo wyboru kandydatów na prezesów i wiceprezesów SW, przedstawiania kandydatów na stanowiska sędziowskie oraz wyboru pełnych składów kolegiów sądów wojewódzkich. Kolegia pozostały głównie organami o charakterze opiniodawczym, uzyskując dodatkowo kompetencje decyzyjne $\mathrm{w}$ zakresie wyrażania zgody na powoływanie i odwoływanie prezesów i wiceprezesów SR oraz na delegowanie sędziego do pełnienia obowiązków w innym sądzie na obszarze właściwości danego SW na czas nie dłuższy niż jeden miesiąc $w$ ciągu roku, czy też rozpatrywania odwołań od rozstrzygnięć prezesa SW w sprawach podjęcia dodatkowego zatrudnienia

Ustawa z dnia 20 września 1984 r. o Sądzie Najwyższym (Dz. U. Nr 45, poz. 241). sqdów oprac. J Szarycz, Warszawa 1989, s. 10-15; L C rozziqzań ustawey z 20 czerwea 1985 r. Prazwo o ustroju sadów powszechnych "Nowe Prawo" 1987, nr 7-8, s. 26. Najwyższym, o Naczelnym Sądzie Administracyjnym, o Trybunale Konstytucyjnym, o ustroju sądów wojskowych i Prawo o notariacie (Dz. U. Nr 73, poz. 436). 
przez sędziego. Powołano wówczas także Krajową Radę Sądownictwa ${ }^{36}$, organ składający się z przedstawicieli wszystkich trzech władz - ustawodawczej, wykonawczej i sądowniczej, który uzyskał szerokie kompetencje w zakresie wyrażania opinii w sprawach ustroju i funkcjonowania sądownictwa i sędziów.

Aktualnie, na podstawie przepisów Prawa o ustroju sądów powszechnych z 2001 r. ${ }^{37}$, organy samorządowe, do których zalicza się zgromadzenia ogólne sędziów apelacji i okręgu oraz zebrania sędziów danego sądu, jak również wybierane przez zgromadzenia kolegia w sądach apelacyjnych i okręgowych, które zalicza się obecnie do organów sądów, posiadają przede wszystkim kompetencje konsultacyjne. Organy te opiniują kandydatów na stanowiska prezesów, wiceprezesów i sędziowskie, wypowiadają się na temat działalności sądów i spraw zawodowych sędziów. Zbliżono się więc w tym zakresie ponownie do koncepcji resortowej z lat 1980-81 samorządu konsultacyjnego.

Zmiany w ramach struktur i kompetencji organów samorządu sędziowskiego, do których dochodziło na przestrzeni blisko 35 lat od opisywanych wydarzeń pokazują, iż sprawa ta nie jest rozstrzygnięta w sposób ostateczny. Koncepcje samorządu sędziowskiego, które kształtowała dyskusja w środowisku sędziowskim i resorcie sprawiedliwości w latach 1980-81, były realizowane $\mathrm{w}$ ramach kolejnych reform ustroju sądownictwa. $Z$ tej perspektywy przedstawione koncepcje sędziowskie i resortowe tego okresu mogą stanowić bogaty materiał komparatystyczny dla dalszej dyskusji nad kształtem i zakresem kompetencji samorządu sędziowskiego.

\section{Bibliografia}

Berutowicz W., Mokry J., Organizacja ochrony prawnej w PRL, Warszawa 1987.

Garlicki L., Zasady ustroju sądów w PRL (na tle rozwiązań ustawy z 20 czerwca 1985 r. - Prawo o ustroju sądów powszechnych, „Nowe Prawo” 1987, nr 7-8.

Kauba K. , "Solidarność” w resorcie sprawiedliwości, „Tygodnik Solidarność” 1981, nr 24.

Machcewicz K., Samorzad sędziowski, „Tygodnik Solidarność” 1981, nr 36.

Obywatelskie Centrum Inicjatyw Ustawodawczych Solidarności 1980-1990, oprac. Barczyk K., Grodziski S., Grzybowski S., Warszawa 2001.

Pomian G., Polska „Solidarności”, Paryż 1982.

Problemów jest mnóstwo - rozmowa z członkami Krajowej Komisji Koordynacyjnej NSZZ „Solidarność” Pracowników Wymiaru Sprawiedliwości, „Gazeta Prawnicza" 1981, nr 9. 
Rudnicki S., O praworządności i niepraworządności w wymiarze sprawiedliwości, „Tygodnik Powszechny" 1981, nr 24.

Rzepliński A., Sądownictwo w PRL, Londyn 1990.

Sąd Najwyższy w PRL, red. M. Rybicki, Wrocław 1983.

"Solidarność" pracowników wymiaru sprawiedliwości - rozmowa Jolanty Strzeleckiej z sędzią Adamem Strzemboszem, „Tygodnik Solidarność” 1981, nr 10.

Stanowska M., Strzembosz A., Sędziowie warszawscy w czasie próby 1981-1988, Warszawa 2005.

Strzembosz A., O samorządne sądownictwo w samorzadnej Rzeczypospolitej, „Tygodnik Solidarność" 1981, nr 33.

Strzembosz A., "Solidarność” o prawie i praworządności, „Gazeta Prawnicza” 1981, nr 15-16.

Szarycz J., Sędziowie i sady w Polsce w latach 1918-1988, Warszawa 1988.

Ślężak J., Dlaczego polskie sądownictwo powinno być samorządne?, „Tygodnik Solidarność" 1981, nr 11.

Ustrój sąów, oprac. J. Szarycz, Warszawa 1989.

Walczak R., Polityka, sady, prokuratura, Warszawa 1990.

Walczak R., Sprawowanie kierowniczej roli partii w sadach i prokuraturze w Polsce Ludowej (studium politologiczne), Warszawa 1987.

Włodyka S., Organizacja wymiaru sprawiedliwości w PRL, Warszawa 1963.

Wreszcie partner - rozmowa z przedstawicielami NSZZ Pracowników Wymiaru Sprawiedliwości, „Gazeta Prawnicza” 1981, nr 7-8. 